\title{
pH influences the biocompatibility of methylene blue solutions
}

\author{
David Jonathan Rodrigues Gusman ${ }^{1} \cdot$ Luciano Tavares Angelo Cintra $^{2}$. \\ Vivian Cristina Noronha Novaes ${ }^{1}$ - Henrique Rinaldi Matheus ${ }^{1}$. \\ Nathália Januario de Araujo ${ }^{1}$. Juliano Milanezi de Almeida ${ }^{1}$
}

Received: 22 August 2016 / Accepted: 1 May 2017 / Published online: 23 May 2017

(C) Springer-Verlag Berlin Heidelberg 2017

\begin{abstract}
Objective The aim of this study was to investigate the biocompatibility of methylene blue at different $\mathrm{pH}$ levels through the method of implantation in subcutaneous tissue.

Materials and methods Eighty-four sterilized polyethylene tubes were allocated in the subcutaneous tissue of 28 rats, each one receiving four tubes, set into four groups: group tube (G$\mathrm{T}$ ) - empty tube, fibrin group (G-F) - tube filled with fibrin sponge, group methylene blue $\mathrm{pH} 7(\mathrm{G}-\mathrm{MB} / \mathrm{pH}$ 7)-tube filled with fibrin sponge soaked by methylene blue $(100 \mu \mathrm{g} / \mathrm{ml})$ at $\mathrm{pH} 7.0$, and group methylene blue $\mathrm{pH} 1$ (G$\mathrm{MB} / \mathrm{pH}$ 1) - tube filled with fibrin sponge and soaked by methylene blue $(100 \mu \mathrm{g} / \mathrm{ml})$ at $\mathrm{pH} 1.0$. After 7,15 , and 30 days, seven animals from each group were euthanized, and the tubes involved by the surrounding tissue were removed and fixed with $4 \%$ buffered formaldehyde solution. The collected pieces were processed and histological sections $(4 \mu \mathrm{m})$ were stained with hematoxylin and eosin and analyzed by light microscopy. Scores were assigned to analysis of histopathologic parameters. The results were statistically analyzed by the Kruskal-Wallis test $(p \leq 0.05)$.

Results At 7 and 30 days, the G-MB/pH 1 group showed no significant difference in the G-T control group, while G-MB/ pH 7 had a significant increase on tissue reaction, also when
\end{abstract}

Juliano Milanezi de Almeida

jumilanezi@hotmail.com

1 Department of Surgery and Integrated Clinic, Division of Periodontics, São Paulo State University (Unesp), School of Dentistry, Araçatuba - R. José Bonifácio, 1193, CEP 16015-050 Sao Paulo, Brazil

2 Department of Endodontics, São Paulo State University (Unesp), School of Dentistry, Araçatuba - R. José Bonifácio, 1193, CEP 16015-050 Sao Paulo, Brazil compared to G-T. At 15 days, there was no statistical difference between the groups.

Conclusion Within the limits of this study, it is concluded that methylene blue at $\mathrm{pH} 1.0$ provides better biocompatibility than at $\mathrm{pH}$ 7.0.

Keywords Biocompatibility testing · Subcutaneous tissue · Hydrogen-ion concentration $\cdot$ Methylene blue

\section{Introduction}

The capacity of a foreign material to reside in an organism by making contact with an organism's living matter (tissue or organ) is called biocompatibility [1,2]. Foreign material needs to be accepted by tissues within physiological limits, and nonbiocompatible dental materials that negatively affect patients have become an increasing public concern $[1,3]$.

One of the main substances used in infections treatment is methylene blue, mostly combined with antimicrobial photodynamic therapy (aPDT), since it has a high degree of selectivity for damaging gram-positive and gram-negative bacteria [3].

Methylene blue is a photosensitizing agent, activated by light at a specific wavelength $(660 \mathrm{~nm})$ that corresponds to maximum absorbance. The combination of visible light irradiation and photoactivated substances triggers the photodynamic process [4-8]. This process produces free radicals, singlet oxygen, and other reactive oxygen species, leading to photooxidation of organic matter $[9,10]$. The lethal photosensitization of microorganisms must involve changes mediated by singlet oxygen in the membranes and/or plasma membrane proteins and DNA. [11-16].

Thereby, aPDT serves as a noninvasive therapy for infection control and has been used as adjuvant in the treatment of 
chronic [17] and aggressive [18] periodontitis, periimplantitis [19], apical periodontitis [20], after impacted third molar removal [21], endodontic treatment [20,22] and retreatment [23], endodontic surgery [24], and it may be considered promising for treatment of dental caries lesions [25].

For chronic and aggressive periodontitis, scaling and root planning (SRP) is considered the standard treatment, providing clinical improvements by disrupting subgingival biofilm, decreasing amount of bacteria, and delaying the repopulation of microorganisms [26, 27]. However, difficulties in accessing furcation areas and root concavities and difficulty in removing bacteria that has penetrated into dentin tubules [17, 28, 29] demonstrate that SRP may not be completely effective, and for these reasons, aPDT has been recommended [17].

On the other hand, acidic substances such as citric acid ( $\mathrm{pH}$ 1), phosphoric acid ( $\mathrm{pH} 1.02$ ), boric acid ( $\mathrm{pH} 4.9$ ), ethylenediaminetetraacetic acid (EDTA) (pH 7.0-7.4), and tetracycline (pH 2.2) are commonly used for chemical conditioning of root canal walls and the outer root surface [30-32]. The acidic root surface modifier substances are intended to detoxify the root surface, removing the smear layer and promoting demineralization, increasing the adhesion of fibrin networks and fibroblasts cells to the root surfaces, and leading to exposure of the collagen matrix, favoring periodontal tissue repair and regeneration [20]. Moreover, in recent years, various studies have proposed the use of aPDT in different treatments associated with various photosensitizing agents, but all with substances with alkaline and neutral $\mathrm{pH}$.

Considering all these points, it is important to evaluate the biocompatibility of solutions used in combination with aPDT, especially the influence of the $\mathrm{pH}$ levels of these solutions. Since the hypothesis is that the tissue behavior against acidic methylene blue could be as healthy as against neutral methylene blue, the aim of this study was to investigate the biocompatibility of methylene blue with different $\mathrm{pH}$ levels through the method of implantation in subcutaneous tissue (ISO 10993-6/2007).

\section{Materials and methods}

\section{Animals}

Twenty-eight, 4-month-old, male rats (Rattus norvegicus Albinus, Wistar), weighing 250-300 g (UNESP, Dental School of Aracatuba, Animal Care Unit) were kept in plastic cages with access to food and water ad libitum in a room with 12-h light/12-h dark cycles and temperature between 22 and $24{ }^{\circ} \mathrm{C}$. The research protocol was approved by the Ethics Committee in Animal Experimentation (00310-2016) at Universidade Estadual Paulista - Julio de Mesquita Filho Dental School of Araçatuba.

\section{Arrangement of the tubes}

Polyethylene sterilized tubes (CPL Medical's, Sao Paulo, SP, Brazil) with $1.6 \mathrm{~mm}$ internal diameter, $2.0 \mathrm{~mm}$ external diameter, and $10.0 \mathrm{~mm}$ length were used. The materials that filled the tubes were fibrin sponge, methylene blue $\mathrm{pH} 7.0$ (Azul de metileno- $\mathrm{pH} 7.0,100 \mu \mathrm{g} / \mathrm{ml}$-Apothicário, Araçatuba, São Paulo, Brazil), and methylene blue pH 1.0 (Azul de metileno-pH 1.0, $100 \mu \mathrm{g} / \mathrm{ml}$-Apothicário, Araçatuba, São Paulo, Brazil). Citric acid $(60 \mu \mathrm{g} / \mathrm{ml})$ was used to reach $\mathrm{pH} 1$ in the acidic methylene blue solution. Both methylene blue solutions were $98.5 \%$ pure.

\section{Experimental groups}

The tubes were separated into four experimental groups $(n=7)$ : tube without any filling as control group (G-T); group filled with fibrin sponge (G-F); group filled with fibrin sponge and soaked by methylene blue $\mathrm{pH} 7.0(\mathrm{G}-\mathrm{MB} / \mathrm{pH}$ 7); and group filled with fibrin sponge soaked by methylene blue pH $1.0(\mathrm{G}-\mathrm{MB} / \mathrm{pH} 1)$.

\section{Subcutaneous implantation}

The animals were anesthetized by intramuscular injection of ketamine $(70 \mathrm{mg} / \mathrm{kg}$ - Francotar — Virbac do Brasil Ind. e Com. Ltda, Roseira, Brazil) and xylazine $(6 \mathrm{mg} / \mathrm{kg}$ Rompum-Bayer S. A., São Paulo, Brazil). The surgical procedure was similar to other studies [33,34]. The dorsal side of the rats was trichotomized and disinfected with $0.2 \%$ chlorhexidine digluconate (Colgate-Palmolive, New York, NY). A 2-cm incision was made in the head-to-tail direction with a 15 Bard-Parker blade (Franklin Lakes, NJ). Two pockets on each side were created in the cranial portion (housing two tubes) and in the caudal portion (housing two tubes) by blunt dissection, and the tubes were implanted in the subcutaneous tissue and the skin was sutured with black silk wire 4-0 (Johnson \& Johnson/Ethicon).

\section{Experimental periods and laboratory procedures}

The animals were euthanized at 7-, 15-, and 30-day intervals by thiopental $(150 \mathrm{mg} / \mathrm{kg}$ - Thiopentax — Cristália—Produtos Quím. Farm. Ltda, São Paulo, Brazil) and lidocaine (6 mg/kg - Lidovet-Bravet. Ltda, Rio de Janeiro, Brazil). The tubes and surrounding tissue were removed in blocks and fixed in $4 \%$ buffered formaldehyde solution. The specimens were processed in paraffin in order to obtain $4-\mu \mathrm{m}$ thick sections of tissue prepared longitudinally through the midline of the tubes and stained with hematoxylin-eosin. 


\section{Histological analysis}

An average value for each animal was obtained from the total cells counted in ten different areas under $\times 400$ magnification. The analysis was performed by a blind examiner using a light microscope (Olympus BX 50 F4, Olympus Optical Co., Ltd., Tokyo, Japan). The images were recorded using a digital camera (Olympus DP 10, Olympus Optical Co. Ltd., Tokyo, Japan) connected to the microscope.

Reactions in the edges of tissues in contact with the materials on the opening of the tubes were analyzed and scored in accordance with a system reported in previous studies [33-35]. The inflammatory reactions were categorized as:

- Score 0 , without inflammatory cells

- Score 1, with mild inflammation (cells <25)

- Score 2, with moderate inflammation (cells = 25-125)

- Score 3, with severe inflammation (>125 cells)

The thickness of fibrous capsules when analyzed was considered to be:

- Thin when $<150 \mu \mathrm{m}$

- $\quad$ Thick at $>150 \mu \mathrm{m}$

Necrosis was recorded as present or absent and a mean of the number of cells for each group was obtained from ten separate areas and ranked according to the scores $0-3$.

\section{Statistical analysis}

The measurements were repeated twice to ensure reproducibility, and median and range of the grades were calculated. Results were statistically analyzed by Kruskal-Wallis tests $(p<0.05)$.

\section{Results}

\section{Control groups (G-T)}

At 7 days, moderate inflammatory cell infiltration consisting of lymphocytes and macrophages was present in the fibrous capsule (Fig. 1a). At days 15 and 30, the connective tissue was well organized, and infiltration of a few chronic inflammatory cells was observed (Fig. 1b, c). The fibrous capsule surrounding the tube was thin, with few chronic inflammatory cells at 15 and 30 days (Fig. 1b, c).

\section{Control groups (G-F)}

At 7 days, severe inflammation cell infiltration consisting of lymphocytes and macrophages was present in the fibrous capsule (Fig. 1d). The observed intensity of inflammation was reduced at 15 and 30 days (Fig. 1e, f), becoming moderate and mild, respectively. The fibrous capsule near the tube was comparatively thin at 30 days (Fig. 1f).

\section{Test group (G-MB/pH 7)}

At 7 days, severe inflammation cell infiltration consisting of lymphocytes and macrophages was present in the fibrous capsule (Fig. 1g). However, at 15 and 30 days, moderate inflammatory cell infiltration consisting of lymphocytes and macrophages was present in the fibrous capsule (Fig. 1h, i), which was considered thin at 30 days (Fig. 1i).

\section{Test group (G-MB/pH 1)}

At 7 and 15 days (Fig. 1j, k), moderate inflammation cell infiltration consisting of lymphocytes and macrophages was present in fibrous capsule. At 30 days (Fig. 11), mild inflammation was observed. The intensity of the inflammation and the thickness of the fibrous capsule were reduced by day 30 (Fig. 11), with fewer chronic inflammatory cells consisting of lymphocytes and macrophages present in the thin fibrous capsule.

\section{Comparison between the groups}

The data for each time point were compared, as shown in Table 1. At days 7 and 30, there were statistically significant differences between inflammatory cell numbers in the control group and the G-MB/pH 7 group ( $p=0.0014$ and 0.0010 , respectively). At 7 days, G-MB/pH 1 (median score 2) had no significant difference with G-T group (median score 1), and the G-MB/pH 7 (median score 3) group was statistically significant, showing more tissue reaction. At 15 days, no significant difference between the groups was observed $(p=0.0051)$. At 30 days, G-MB/pH 1 (median score 1) had no significant difference with G-T (median score 1), and G$\mathrm{MB} / \mathrm{pH} 7$ (median score 2) group was statistically significant, showing more tissue reaction.

\section{Discussion}

Nowadays, the development of biomaterials must consider the aesthetics, strength, functional aspects of the material, and also its biocompatibility with connective tissue [1]. Implantation of sterilized polyethylene tubes in the subcutaneous connective tissues of rats has been widely used to evaluate biocompatibility materials according to ISO 10993-6/ 2007 standards $[33,36]$. The aim of this study was to investigate the biocompatibility of methylene blue at different $\mathrm{pH}$ levels. 

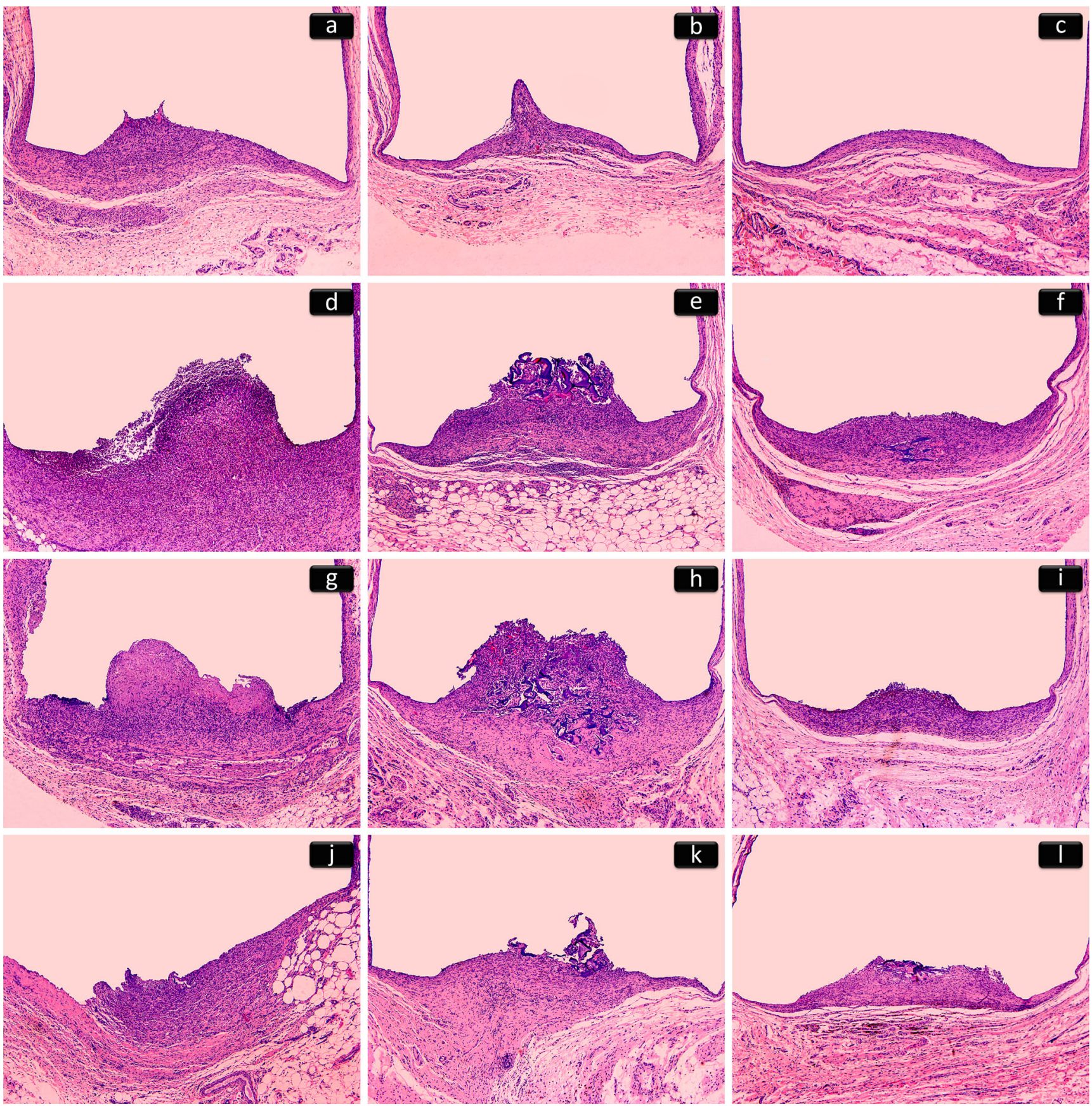

Fig. 1 G-T. a Thick fibrous capsule and moderate inflammatory cell infiltration consisting of lymphocytes and macrophages (7 days; hematoxylin-eosin; original magnification, $\times 50)$. b, $\mathbf{c}$ Thin fibrous capsule and infiltration of a few chronic inflammatory cells (15 and 30 days; hematoxylin-eosin, $\times 50$ ). G-F d Thick fibrous capsule and severe inflammatory cell infiltration consisting of lymphocytes and macrophages (7 days; hematoxylin-eosin; original magnification, $\times 50$ ). e Thick fibrous capsule and moderate inflammatory cell infiltration (15 days; hematoxylin-eosin; original magnification, $\times 50$ ). $\mathbf{f}$ Thin fibrous capsule and mild inflammatory cell infiltration (30 days; hematoxylin-eosin; original magnification, $\times 50$ ). G-MB/pH 7. g Thick

fibrous capsule and severe inflammatory cell infiltration consisting of lymphocytes and macrophages (7 days; hematoxylin-eosin; original magnification, $\times 50)$. h Thick fibrous capsule and moderate inflammatory cell infiltration (15 days; hematoxylin-eosin; original magnification, $\times 50$ ). i Thin fibrous capsule and moderate inflammatory cell infiltration (30 days; hematoxylin-eosin; original magnification, $\times 50)$. G-MB/pH 1. j, k Thick fibrous capsule and moderate inflammatory cell infiltration consisting of lymphocytes and macrophages ( 7 and 15 days; hematoxylin-eosin; original magnification, $\times 50$ ). I Thin fibrous capsule and mild inflammatory cell infiltration (30 days; hematoxylin-eosin; original magnification, $\times 50$ )

Methylene blue is used in aPDT as a photosensitizer for root decontamination [37] and could interact with connective

tissue in different ways. In subgingival SRP, the curettes reach the connective tissue and facilitate the input of methylene blue 
Table 1 Inflammatory scores and size of the fibrous capsule at different observation times

\begin{tabular}{|c|c|c|c|c|c|c|c|c|c|}
\hline \multirow[t]{2}{*}{ Time/ $p$ value } & \multirow[t]{2}{*}{ Material } & \multicolumn{4}{|c|}{ Scores } & \multirow[t]{2}{*}{ Median } & \multicolumn{2}{|c|}{ Capsule } & \multirow[t]{2}{*}{$n$} \\
\hline & & 0 & 1 & 2 & 3 & & Thin & Thick & \\
\hline \multirow{4}{*}{$\begin{array}{l}7 \text { days } \\
p=0.0014\end{array}$} & G-T & 0 & 4 & 3 & 0 & $1^{\mathrm{a}}$ & 4 & 3 & 7 \\
\hline & $\mathrm{G}-\mathrm{F}$ & 0 & 0 & 3 & 4 & $3^{b}$ & 2 & 5 & \\
\hline & G-MB/pH 7 & 0 & 0 & 3 & 4 & $3^{b}$ & 2 & 5 & \\
\hline & G-MB/pH 1 & 0 & 1 & 3 & 3 & $2^{\mathrm{a}}$ & 2 & 5 & \\
\hline \multirow{4}{*}{$\begin{array}{l}15 \text { days } \\
p=0.0051\end{array}$} & G-T & 0 & 5 & 2 & 0 & $1^{\mathrm{a}}$ & 5 & 2 & $\gamma$ \\
\hline & G-F & 0 & 1 & 5 & 1 & $2^{\mathrm{a}}$ & 2 & 5 & \\
\hline & G-MB/pH 7 & 0 & 1 & 4 & 2 & $2^{\mathrm{a}}$ & 2 & 5 & \\
\hline & G-MB/pH 1 & 0 & 1 & 5 & 1 & $2^{\mathrm{a}}$ & 2 & 5 & \\
\hline \multirow{4}{*}{$\begin{array}{l}30 \text { days } \\
p=0.0010\end{array}$} & G-T & 4 & 3 & 0 & 0 & $0^{\mathrm{a}}$ & 6 & 1 & 7 \\
\hline & G-F & 0 & 4 & 3 & 0 & $1^{\mathrm{a}}$ & 4 & 3 & \\
\hline & G-MB/pH 7 & 0 & 3 & 4 & 0 & $2^{\mathrm{b}}$ & 4 & 3 & \\
\hline & G-MB/pH 1 & 0 & 4 & 3 & 0 & $1^{\mathrm{a}}$ & 5 & 2 & \\
\hline
\end{tabular}

Different superscript letters indicate statistical difference among the groups $(p \leq 0.05)$

into it [38]. Other ways methylene blue could interact with connective tissue are after periodontal surgery, such as surgical SRP [39] and subepithelial connective tissue graft [40].

Its use at an acidic $\mathrm{pH}$ level could increase the effectiveness of these therapies, since the acidic substances could improve healing and periodontal regeneration after an SRP procedure, as shown by Nanda et al.'s [32] study in vitro; however, the clinical benefits are discussed in the literature.

In a systematic review by Mariotti [41], it was concluded that the use of citric acid, tetracycline, or EDTA to modify the root surface provides no clinically significant benefit for regeneration in patients with chronic periodontitis. However, a meta-analysis found 16 studies that applied tetracycline as an adjunct to SRP, finding benefits in reducing probing depth after statistical analysis [42].

Clinical results without benefits can be explained by Lan et al. [43] because low pH substances such as citric acid exhibit a potentially necrotizing effect, inducing cell death and cell structural changes within 30-s intervals, generating superficial necrosis. However, the present study did not find a necrotizing effect of the methylene blue solution at a $\mathrm{pH}$ level of 1.0. Cellular and tissue necrosis caused by exposure to acidic substances may not be uniquely explained due to its low $\mathrm{pH}$, since several different characteristics, such as volume, acid strength, concentration, and origin (organic or inorganic), can positively or negatively affect this process.

Thus, aPDT benefits through increasing cell proliferation on infected wounds and stimulates an angiogenic response $[44,45]$, reduces the amount of pro-inflammatory interleukins (IL-1 $\alpha$, IL-1 $\beta$, IL-2), induces proliferation of marked fibroblasts [46, 47], and increases FGF2 expression enhancing the repair process. These benefits could be increased by methylene blue at an acidic $\mathrm{pH}$ level once it is exposed to the collagen matrix [20, 48]. However, other studies must be performed applying methods to evaluate their photochemical interactions.

$\mathrm{G}-\mathrm{MB} / \mathrm{pH} 1$ group did not show statistical difference in any experimental period compared to the positive control group. On the other hand, the $\mathrm{G}-\mathrm{MB} / \mathrm{pH} 7$ group showed greater presence of inflammatory cell infiltration, mainly lymphocytes and macrophages, present in a fibrous capsule at 7 and 30 days. All groups showed an improvement in the inflammatory process over long time, but the G-MB/pH 7 group presented more concentration of the inflammatory infiltrate.

Previous studies indicate that alkaline and acidic conditions influence negatively inflammatory cells; however, in this study, an acidic substance had better results [49-51]. Saghiri et al. 2013 analyzed the inflammatory response of Geristore (resin glass ionomer) in subcutaneous tissue of rats and reported that the fact of it being a substance of low $\mathrm{pH}$ may explain the induction of significantly more inflammation [49]. However, as mentioned by the authors [49], Geristore releases five monomers of Bis-GMA, Bis-DMA, TEGDMA, UDMA, and Bisphenol A. As resin monomers are reported to show cytotoxic effects $[52,53]$ and might be capable of tumor initiation at relatively low concentrations [54], this may be listed as another plausible explanation for the exacerbated inflammatory response.

Citric acid was the substance used to reach $\mathrm{pH} 1$ in the methylene blue solution. Citric acid was the less toxic and the most effective among all acidic substances tested by Register and Burdick 1975 [55]. Moreover, Prasad et al. 2012 [56] concluded that citric acid is more effective in removing the smear layer, exposing the root collagen and causes greater degree of morphological alterations (mean diameter, mean total surface area occupied by dentinal tubules). These characteristics may allow cementum to form within the tubules. Also, the exposed root collagen fibers can splice with the collagen fibrils of a soft tissue graft or flap (collagen splicing) resulting in collagen adhesion.

These different results of acidic substances may also be explained by acid strength, which is the ability of the acids to lose a proton $\left(\mathrm{H}^{+}\right)[57,58]$. The acid strength could be adjusted by different factors, for instance, form of physical state, topology structure and morphology, and crystallinity in addition to the chemical compositions [57]. However, other animal studies and subsequent clinical studies are necessary to evaluate the use of methylene blue at $\mathrm{pH}$ 1.0.

\section{Conclusion}

Within the limits of this study, it is concluded that methylene blue at $\mathrm{pH} 1.0$ provides better biocompatibility than at $\mathrm{pH} 7.0$. 


\section{Compliance with ethical standards}

Conflict of interest The authors declare that they have no conflict of interest.

Funding The work has no source of funding.

Ethical approval All applicable international, national, and/or institutional guidelines for the care and use of animals were followed. All procedures performed in studies involving animals were in accordance with the ethical standards of the institution or practice at which the studies were conducted.

Informed consent For this type of study, formal consent is not required.

\section{References}

1. Pătroi D, Gociu M, Prejmerean C, Colceriu L, Silaghi Dumitrescu L, Moldovan M, Naicu V (2013) Assessing the biocompatibility of a dental composite product. Romanian J Morphol Embryol 54(2): 321-326

2. de Campos-Pinto MM, de Oliveira DA, Versiani MA, Silva-Sousa YT, de Sousa-Neto MD, da Cruz Perez DE (2008) Assessment of the biocompatibility of epiphany root canal sealer in rat subcutaneous tissues. Oral Surg Oral Med Oral Pathol Oral Radiol Endod 105(5):e77-e81

3. Grecca FS, Kopper PM, Santos RB, Fossati AC, Carrard VC, Acasigua GA, Figueiredo JA (2011) Biocompatibility of RealSeal, its primer and AH Plus implanted in subcutaneous connective tissue of rats. J Appl Oral Sci 19(1):52-56

4. Lipson RL, Baldes EJ, Olsen AM (1961) The use of a derivate of haematoporphyrin in tumor detection. J Natl Cancer Inst 26:1-11

5. Dougherty TJ (1987) Photosensitizers: therapy and detention of malignant tumors. Phtochem Photobiol 45:879-889

6. Modica-Napolitano JS, Joyal JL, Ara G, Oseroff AR, Aprille JR (1990) Mitochondrial toxicity of cationic photosensitizers for photochemotherapy. Concer Res 50(24):7786-7781

7. Tardivo JP, Del Giglio A, Oliveira CS, Gabrielli DS, Junqueira HC et al (2005) Methylene blue in photodynamic therapy: from basic mechanisms to clinical applications. Photodiagn Photodyn Ther 2/3:175-191

8. Tardivo JP, Del Giglio A, Paschoal LH, Baptista MS (2006) A new PDT protocol to treat AIDS-related Kaposi's sarcoma. Photomed Laser Surg 24(4):528-531

9. Foote CS (1968) Mechanisms of photosensitized oxidation. There are several different types of photosensitized oxidation which may be important in biological systems. Science 162(857):963-970

10. Wilkson F, Helman WP, Ross AB (1995) Rate constants for the decay and reactions of the lowest electronically excited singlet state of molecular oxygen in solution. An expanded and revised compilation. J Phys Chem Ref Data 24:663-1021

11. Santin GC, Oliveira DSB, Galo R, Borsatto MC, Corona SAM (2014) Antimicrobial photodynamic therapy and dental plaque: a systematic review of the literature. ScientificWorldJournal 2014(24538):1-9

12. Almeida JM, Theodoro LH, Bosco AF, Nagata MJH, Bonfante S, Garcia VG (2008) Treatment of experimental periodontal disease by photodynamic therapy in rats with diabetes. J Periodontol 79(11):2156-2165

13. Bhatti M, Mac Robert A, Meghji S, Henderson B, Wilson M (1998) A study of the uptake of toluidine blue $\mathrm{O}$ by Porphyromonas gingivalis and the mechanism of lethal photosensitization. Photochem Photobiol 68:370-376

14. Maisch T, Szeimies RM, Jori G, Abels C (2004) Antibacterial photodynamic therapy in dermatology. Photochem Photobiol Sci 3: 907-917

15. Meisel P, Kocher T (2005) Photodynamic therapy for periodontal diseases: state of the art. J Photochem Photobiol B 79:159-170

16. Jori G (2006) Photodynamic therapy of microbial infections: state of the art and perspectives. J Environ Pathol Toxicol Oncol 25:505520

17. Betsy J, Prasanth CS, Baiju KV, Prasanthila J, Subhash N (2014) Efficacy of antimicrobial photodynamic therapy in the management of chronic periodontitis: a randomized controlled clinical trial. J Clin Periodontol 41(6):573-581

18. Vohra F, Akram Z, Safii SH, Vaithilingam RD, Ghanem A, Sergis $\mathrm{K}$, Javed F (2016) Role of antimicrobial photodynamic therapy in the treatment of aggressive periodontitis: a systematic review. Photodiagn Photodyn Ther 13:139-147

19. Al Amri MD, Kellesarian SV, Ahmed A, Al-Kheraif AA, Romanos GE, Javed F (2016) Efficacy of periimplant mechanical debridement with and without adjunct antimicrobial photodynamic therapy in patients with type 2 diabetes mellitus. Photodiagn Photodyn Ther 14:166-169

20. Silva LA, Novaes AB Jr, de Oliveira RR, Nelson-Filho P, Santamaria M Jr, Silva RA (2012) Antimicrobial photodynamic therapy for the treatment of teeth with apical periodontitis: a histopathological evaluation. J Endod. 38(3):360-366

21. Batinjan G, Zore Z, Čelebić A, Papić M, Gabrić Pandurić D, Filipović Zore I (2014) Thermographic monitoring of wound healing and oral health-related quality of life in patients treated with laser (aPDT) after impacted mandibular third molar removal. Int J Oral Maxillofac Surg 43(12):1503-1508

22. Tennert C, Feldmann K, Haamann E, Al-Ahmad A, Follo M, Wrbas KT, Hellwig E, Altenburger MJ (2014) Effect of photodynamic therapy (PDT) on Enterococcus faecalis biofilm in experimental primary and secondary endodontic infections. BMC Oral Health $14: 132$

23. Jurič IB, Plečko V, Pandurić DG, Anić I (2014) The antimicrobial effectiveness of photodynamic therapy used as an addition to the conventional endodontic re-treatment: a clinical study. Photodiagn Photodyn Ther 11(4):549-555

24. Garcez AS, Arantes-Neto JG, Sellera DP, Fregnani ER (2015) Effects of antimicrobial photodynamic therapy and surgical endodontic treatment on the bacterial load reduction and periapical lesion healing. Three years follow up. Photodiagn Photodyn Ther 12(4):575-580

25. Diniz IM, Horta ID, Azevedo CS, Elmadjian TR, Matos AB, Simionato MR, Marques MM (2015) Antimicrobial photodynamic therapy: a promise candidate for caries lesions treatment. Photodiagn Photodyn Ther 12(3):511-518

26. Nagarakanti S, Gunupati S, Chava VK, Reddy BV (2015) Effectiveness of subgingival irrigation as an adjunct to scaling and root planing in the treatment of chronic periodontitis: a systematic review. J Clin Diagn Res 9(7):ZE06-ZE09

27. Annaji S, Sarkar I, Rajan P, Pai J, Malagi S, Bharmappa R, Kamath V (2016) Efficacy of photodynamic therapy and lasers as an adjunct to scaling and root planing in the treatment of aggressive periodontitis - a clinical and microbiologic short term study. J Clin Diagn Res 10(2):ZC08-ZC12

28. Sgolastra F, Petrucci A, Severino M, Graziani F, Gatto R, Monaco A (2013) Adjunctive photodynamic therapy to non-surgical treatment of chronic periodontitis: a systematic review and meta-analysis. J Clin Periodontol 40(5):514-526

29. Kikuchi T, Mogi M, Okabe I, Okada K, Goto H, Sasaki Y, Fujimura T, Fukuda M, Mitani A (2015) Adjunctive application of 
antimicrobial photodynamic therapy in nonsurgical periodontal treatment: a review of literature. Int J Mol Sci 16(10):24111-24126

30. Abed AM, Farhad SZ, Farhad A, Barekatain M, Mafi M, Abooie MS (2013) Debris and smear layer removal efficacy and changes in morphology of dentinal tubules after using citric acid, tetracyclinehydrochloride and mixture of tetracycline and acid and detergent. Dent Res J (Isfahan) 10(2):232-237

31. Sağlam M, Arslan U, Buket Bozkurt Ș, Hakki SS (2013) Boric acid irrigation as an adjunct to mechanical periodontal therapy in patients with chronic periodontitis: a randomized clinical trial. J Periodontol 84(9):1297-1308

32. Nanda T, Jain S, Kaur H, Kapoor D, Nanda S, Jain R (2014) Root conditioning in periodontology-revisited. J Nat Sci Biol Med 5(2):356-358

33. Cintra LT, Watanabe S, Samuel RO, da Silva Facundo AC, de Azevedo Queiroz IO, Dezan-Júnior E, Gomes-Filho JE (2014) The use of $\mathrm{NaOCl}$ in combination with $\mathrm{CHX}$ produces cytotoxic product. Clin Oral Investig 18(3):935-940

34. Gomes-Filho JE, Silva FO, Watanabe S, Cintra LT, Tendoro KV, Dalto LG, Pacanaro SV, Lodi CS, de Melo FF (2010) Tissue reaction to silver nanoparticles dispersion as an alternative irrigating solution. J Endod. 36:1698-1702

35. Federation Dentaire International recommended standard practices for biological evaluation of dental materials (1980) Federation Dentaire International Commission on Dental Materials, Equipment, and Therapeutics: part 4.11-subcutaneous implantation test. Int Dental J 30:173-174

36. Andolfatto C, da Silva GF, Cornélio AL, Guerreiro-Tanomaru JM, Tanomaru-Filho M, Faria G, Bonetti-Filho I, Cerri OS (2012) Biocompatibility of intracanal medications based on calcium hydroxide. ISRN Dent 2012:904963

37. Garcia VG, Longo M, Gualberto Júnior EC, Bosco AF, Nagata MJ, Ervolino E, Theodoro LH (2014) Effect of the concentration of phenothiazine photosensitizers in antimicrobial photodynamic therapy on bone loss and the immune inflammatory response of induced periodontitis in rats. J Periodontal Res 49(5):584-594

38. Fowler C, Garrett S, Crigger M, Egelberg J (1982) Histologic probe position in treated and untreated human periodontal tissues. J Clin Periodontol 9(5):373-385

39. Andrade PF, Garlet GP, Silva JS, Fernandes PG, Milanezi C, Novaes AB Jr, Palioto DB, Grisi MF, Taba M Jr, Souza SL (2013) Adjunct effect of the antimicrobial photodynamic therapy to an association of non-surgical and surgical periodontal treatment in modulation of gene expression: a human study. J Photochem Photobiol B 126:119-125

40. Karam PS, Sant'Ana AC, de Rezende ML, Greghi SL, Damante CA, Zangrando MS (2016) Root surface modifiers and subepithelial connective tissue graft for treatment of gingival recessions: a systematic review. J Periodontal Res 51(2):175-185

41. Mariotti A (2003) Efficacy of chemical root surface modifiers in the treatment of periodontal disease. A systematic review. Ann Periodontol 8(1):205-226

42. Bonito AJ, Lux L, Lohr KN (2005) Impact of local adjuncts to scaling and root planing in periodontal disease therapy: a systematic review. J Periodontol 76(8):1227-1236

43. Lan WC, Lan WH, Chan CP, Hsieh CC, Chang MC, Jeng JH (1999) The effects of extracellular citric acid acidosis on the viability, cellular adhesion capacity and protein synthesis of cultured human gingival fibroblasts. Aust Dent J 44(2):123-130

44. Sahu K, Sharma M, Dube A, Gupta PK (2015) Topical antimicrobial photodynamic therapy improves angiogenesis in wounds of diabetic mice. Lasers Med Sci 30(7):1923-1929

45. Sahu K, Sharma M, Gupta PK (2015) Modulation of inflammatory response of wounds by antimicrobial photodynamic therapy. Laser Ther 224(3):201-208

46. Alghamdi KM, Kumar A, Moussa NA (2011) Low-level laser therapy: a useful technique for enhancing the proliferation of various cultured cells. Lasers Med Sci 27(1):237-249

47. Pansani TN, Basso FG, Turirioni AP, Kurachi C, Hebling J, de Souza Costa CA (2014) Effects of low-level laser therapy on the proliferation and apoptosis of gingival fibroblasts treated with zoledronic acid. Int J Oral Maxillofac Surg 43(8):1030-1034

48. Franco EJ, Pogue RE, Sakamoto LH, Cavalcante LL, Carvalho DR, de Andrade RV (2014) Increased expression of genes after periodontal treatment with photodynamic therapy. Photodiagn Photodyn Ther 11(1):41-47

49. Saghiri MA, Tanideh N, Garcia-Godoy F, Lotfi M, Karamifar K, Amanat D (2013) Subcutaneous connective tissue reactions to various endodontic biomaterials: an animal study. J Dent Res Dent Clin Dent Prospects 7(1):15-21

50. Saghiri MA, Shokouhinejad N, Lotfi M, Aminsobhani M, Saghiri AM (2010) Push-out bond strength of mineral trioxide aggregate in the presence of alkaline $\mathrm{pH}$. J Endod 36:1856-1859

51. Vosoughhosseini S, Lotfi M, Shahi S, Baloo H, Mesgariabbasi M, Saghiri MA, Zand V, Rahimi S, Ranjkesh B (2008) Influence of white versus gray mineral trioxide aggregate on inflammatory cells. J Endod 34:715-717

52. Geurtsen W, Lehmann F, Spahl W, Leyhausen G (1998) Cytotoxicity of 35 dental resin composite monomers/additives in permanent $3 \mathrm{~T} 3$ and three human primary fibroblast cultures. J Biomed Mater Res 41:474-480

53. Al-Hiyasat A, Darmani H, Milhem M (2005) Cytotoxicity evaluation of dental resin composites and their flowable derivatives. Clin Oral Invest 9:21-25

54. Kleinsasser NH, Schmid K, Sassen AW, Harréus UA, Staudenmaier $\mathrm{R}$, Folwaczny $\mathrm{M}$ et al (2006) Cytotoxic and genotoxic effects of resin monomers in human salivary gland tissue and lymphocytes as assessed by the single cell microgel electrophoresis (Comet) assay. Biomaterials 27:1762-1770

55. Register A, Burdick F (1975) Accelerated reattachment with cementogenesis to dentin, the mineralized in situ. I Optimum range J Periodontol 46:646-655

56. Prasad SS, Radharani C, Varma S, Kumar SV, Sinha S, Bijle MN (2012) Effects of citric acid and EDTA on periodontally involved root surfaces: a SEM study. J Contemp Dent Pract 13(4):446-451

57. Zhang X, Zhao Y, Xu S, Yang Y, Liu J, Wei Y, Yang Q (2014) Polystyrene sulphonic acid resins with enhanced acid strength via macromolecular self-assembly within confined nanospace. Nat Commun 5:3170

58. Arean CO, Delgado MR, Nachtigall P, Thang HV, Rubeš M, Bulánek R, Chlubná-Eliášová P (2014) Measuring the Brønsted acid strength of zeolites - does it correlate with the O-H frequency shift probed by a weak base? Phys Chem Chem Phys 16(21): 10129-10141 